\title{
One-Pot Synthesis of Al-P-O Catalysts and Their Catalytic Properties for $\mathrm{O}$-Methylation of Catechol and Methanol
}

\author{
Dongfei Xu, Jiaan Ren, Shengnan Yue, Xiujing Zou *, Xingfu Shang * and Xueguang Wang
}

Citation: Xu, D.; Ren, J.; Yue, S.; Zou,

X.; Shang, X.; Wang, X. One-Pot

Synthesis of Al-P-O Catalysts and

Their Catalytic Properties for

$O$-Methylation of Catechol and

Methanol. Materials 2021, 14, 5942.

https://doi.org/10.3390/ma14205942

Academic Editors: Irina L. Simakova and Dmitry Yu. Murzin

Received: 27 August 2021

Accepted: 6 October 2021

Published: 10 October 2021

Publisher's Note: MDPI stays neutral with regard to jurisdictional claims in published maps and institutional affiliations.

Copyright: (c) 2021 by the authors. Licensee MDPI, Basel, Switzerland. This article is an open access article distributed under the terms and conditions of the Creative Commons Attribution (CC BY) license (https:/ / creativecommons.org/licenses/by/ $4.0 /)$.
State Key Laboratory of Advanced Special Steel, Shanghai Key Laboratory of Advanced Ferrometallurgy, School of Materials Science and Engineering, Shanghai University, Shanghai 200444, China; xudongfei@shu.edu.cn (D.X.); 18717902659@163.com (J.R.); snyue@shu.edu.cn (S.Y.); wxg228@shu.edu.cn (X.W.)

* Correspondence: xjzou@shu.edu.cn (X.Z.); xfshang@shu.edu.cn (X.S.)

\begin{abstract}
A series of Al-P-O catalysts (Al- $x \mathrm{P}-\mathrm{O})$ were prepared using a P123-assisted one-pot method at different $\mathrm{P} / \mathrm{Al}$ molar ratios and used for $\mathrm{O}$-methylation of catechol and methanol. The influences of the P/Al molar ratio and P123 addition on catalyst structure and surface acid-base characteristics were investigated in detail. Increasing the $\mathrm{P} / \mathrm{Al}$ molar ratio more favored crystalline aluminophosphate. The P123-assisted $\mathrm{Al}^{3+}$ and $\mathrm{PO}_{4}{ }^{3-}$ are known to be stabilized through weak steric force so that the formation of crystalline aluminophosphate could be inhibited at higher $\mathrm{P} / \mathrm{Al}$ molar ratios. The results showed that the prepared Al-P-O catalysts possessed appropriate weak acid and weak base sites, which was beneficial to the reaction of catechol and methanol. The Al-1.1P-O catalyst synthesized with the assistance of P123 exhibited superior catalytic performances, with 52.5\% catechol conversion and higher guaiacol selectivity of $97.6 \%$.
\end{abstract}

Keywords: Al-P-O catalysts; P123-assisted; one-pot method; catechol; O-methylation

\section{Introduction}

Guaiacol is also known as o-hydroxyanisole or o-methoxyphenol. As an important fine chemical raw material and intermediate [1-3], guaiacol and its derivatives are widely used in medicine [4,5], agricultural chemic [6,7], and spices [8], especially in synthesis of vanillin [9-12]. Traditionally, guaiacol is produced mainly by methylation of catechol with halogenated alkanes $\left(\mathrm{CH}_{3} \mathrm{I}, \mathrm{CH}_{3} \mathrm{CH}_{2} \mathrm{Br}\right),\left(\mathrm{CH}_{3}\right)_{2} \mathrm{SO}_{4}$, or dimethyl carbonate (DMC) in the presence of sodium hydroxide by homogeneous reaction [13-15]. In these reaction processes, large amounts of toxic organic compounds required to generate guaiacol would inevitably cause serious environmental concerns. In addition, they involve a lot of secondary reactions and complicated processes, affecting the yield and quality of the products. Therefore, much attention has been paid to developing a green and efficient synthesis process for guaiacol.

Recently, vapour-phase selective $O$-methylation of catechol to synthesize guaiacol, which is an economically and environmentally friendly route for industrial applications, has attracted extensive attention from scientific researchers [16-20]. Methanol is believed to be a very promising candidate for use as a methylation agent for selective $O$-methylation of catechol due to its low toxicity and low cost. The heterogeneous catalysts used for vapourphase selective $O$-methylation of catechol and methanol is the main factor affecting the yield and quality of the guaiacol. It has been widely believed that solid acid-base catalysts were active catalysts for $\mathrm{O}$-methylation of catechol and methanol. Lots of solid acidbase catalysts, such as supported catalysts [13,17,21], molecular sieve-based catalysts [22], phosphate catalysts [16,23-27], Mg-Al hydrotalcites catalysts [18], and oxide or mixed oxide catalysts $[14,28-30]$ exhibit catalytic performance for vapour-phase selective $O$ methylation of catechol and methanol. Among various solid acid-base catalysts, phosphate catalysts, especially aluminophosphates, have been widely used for vapour-phase selective $\mathrm{O}$-methylation of catechol and methanol because of their high activity and low cost. 
Liao et al. [22] found that coating microporous aluminophosphates on mesoporous SBA-15 bearing suitable weak acid-base sites exhibits the relatively high activity of $68.3 \%$ and guaiacol selectivity of $90.6 \%$. Zhu et al. [26] found that aluminophosphates with lower Ti content prepared by non-uniform precipitation methods favored guaiacol formation and catalytic stability. During 450-h reaction, the conversion of catechol is above $84 \%$, and the guaiacol selectivity is around $90 \%$. Liu et al. [27] developed a citric acid route to prepare amorphous mesoporous aluminophosphates with different $\mathrm{P} / \mathrm{Al}$ ratios. Among the prepared samples, $\mathrm{AlP}_{1.1} \mathrm{O}$ showed the highest performance $(88.4 \%$ conversion of catechol and $84.1 \%$ selectivity of guaiacol). These reported aluminophosphate catalysts usually suffer a serious problem of lower guaiacol selectivity and bad stability, increasing the cost of product purification or limiting the application in actual production. Hence, it is still important to develop a simple approach to fabricate aluminophosphates with higher activity, selectivity, and stability for vapor-phase $O$-methylation of catechol with methanol. It has been reported that the catalytic performance of aluminophosphate catalysts could be significantly improved by optimizing catalyst compositions, improving catalyst preparation processes, using additional ligand, carefully selecting operating conditions, etc. [14,25,26].

In this work, a series of Al-P-O catalysts (Al- $x \mathrm{P}-\mathrm{O}$ ) were prepared by a P123-assisted one-pot method at different $\mathrm{P} / \mathrm{Al}$ molar ratios, which exhibited excellent catalytic activity, guaiacol selectivity, and stability for vapour-phase selective $O$-methylation of catechol and methanol. The effects of the P/Al molar ratio and P123 addition on catalyst structure and surface acid-base characteristics were investigated in detail.

\section{Materials and Methods}

\subsection{Catalyst Preparation}

All chemicals were purchased and used without further purification. Pluronic P123 $\left(\mathrm{EO}_{20} \mathrm{PO}_{70} \mathrm{EO}_{20}\right)$ was bought from Sigma-Aldrich Reagent (Shanghai, China). Other chemicals were supplied by Sinopharm Chemical Reagent Co., Ltd. (Shanghai, China).

$\mathrm{AlCl}_{3}(99.0 \%)$ was used as the aluminum source, $\mathrm{H}_{3} \mathrm{PO}_{4}(85 \%)$ was used as the phosphorus source, and the block copolymer P123 $\left(\mathrm{M}_{\mathrm{av}}=5800\right)$ was used as the additional ligand. A series of Al-P-O catalysts with different $\mathrm{P} / \mathrm{Al}$ molar ratios were prepared using a P123-assisted one-pot method. Typically, $44.5 \mathrm{~g} \mathrm{AlCl}_{3}$ and $16.9 \mathrm{~g}$ P123 were firstly dissolved in $200 \mathrm{~mL}$ of deionized water respectively. After that, the aqueous solution of $\mathrm{AlCl}_{3}$ and P123 were directly mixed with vigorous magnetic stirring and heated to $60{ }^{\circ} \mathrm{C}$ in a water bath. Then, a required $\mathrm{H}_{3} \mathrm{PO}_{4}$ was poured into the mixed aqueous solution. Following this, $6 \mathrm{~mol} / \mathrm{L}$ ammonium hydroxide solution were dropped into the above solution until $\mathrm{pH}$ value of the mixture was ca. 9. The mixture was further stirred for $1 \mathrm{~h}$. Then, the mixture was evaporated at $80^{\circ} \mathrm{C}$, dried at $100{ }^{\circ} \mathrm{C}$ for $12 \mathrm{~h}$, and calcined with a heating rate of $2{ }^{\circ} \mathrm{C} / \mathrm{min}$ in air at $550{ }^{\circ} \mathrm{C}$ for $12 \mathrm{~h}$ in sequence. The prepared materials were labelled as $\mathrm{Al}-x \mathrm{P}-\mathrm{O}$, where $x$ represented $\mathrm{Al} / \mathrm{P}$ molar ratio.

For comparison, Al-1.1P-O $\mathrm{O}^{\mathrm{a}}$ was also prepared by the same approach as $\mathrm{Al}-1.1 \mathrm{P}-\mathrm{O}$ without $\mathrm{P} 123$ addition.

\subsection{Catalyst Characterization}

Powder X-ray diffraction (XRD) measurements of the samples were performed with a Germany Bruker D8 Advance ray diffractometer using $\mathrm{Cu} K \alpha$ radiation at $40 \mathrm{kV}$ and

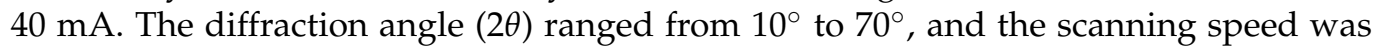
$8^{\circ} / \mathrm{min}$. The crystallite size of $\mathrm{AlPO}_{4}$ was calculated using the full-widths at half maximum (FWHM) of the $\mathrm{AlPO}_{4}(020)$ peak through the Scherrer equation.

$\mathrm{N}_{2}$ adsorption-desorption isotherms were performed on the Micromeritics ASAP 2020 sorptometer at liquid nitrogen temperature $\left(-196^{\circ} \mathrm{C}\right)$. Before the measurement, each catalyst was degassed at $250{ }^{\circ} \mathrm{C}$ for $5 \mathrm{~h}$. The specific surface area $\left(S_{\mathrm{BET}}\right)$ was calculated by the Brunauer-Emmett-Teller (BET) method within the range of relative pressure $P / P_{0}=0.10 \sim 0.30$. The average pore size $\left(D_{\mathrm{a}}\right)$ was calculated using the $\mathrm{BJH}$ method. The pore volume $\left(V_{\mathrm{p}}\right)$ was set as the single point value when $P / P_{0}$ was 0.990 . 
SEM images were acquired by employing a FEI Nova nanoSEM 450 electron microscope. The samples were sprayed with metal layer before testing.

FT-IR spectra were performed on a Germany Bruker TENSOR 27 Fourier transform infrared spectrometer. The structure of the sample and the vibration of the skeleton were made using a $\mathrm{KBr}$ support chip. (The mass ratio of catalyst to $\mathrm{KBr}$ is 1:100).

Temperature programmed desorption (TPD) was performed on a Biode PCA-1200 chemisorption analyzer for the surface acid (base) center strength and number of the catalysts by using $\mathrm{NH}_{3}\left(\mathrm{CO}_{2}\right)$ as the probe molecule and TCD as the detector. Prior to the measurement, a $100 \mathrm{mg}$ sample was accurately weighed and placed in a quartz tube and then heated to $400{ }^{\circ} \mathrm{C}$ at a rate of $10{ }^{\circ} \mathrm{C} / \mathrm{min}$ under Ar flow $(30 \mathrm{~mL} / \mathrm{min})$ for $1 \mathrm{~h}$ to remove the moisture in samples and the residual gas in the test system. Then it was cooled to $50{ }^{\circ} \mathrm{C}$ and exposed to $\mathrm{NH}_{3}\left(\mathrm{CO}_{2}\right)$ for $0.5 \mathrm{~h}$. Ar flow $(30 \mathrm{~mL} / \mathrm{min})$ was purged from the quartz tube to remove the physical adsorption of $\mathrm{NH}_{3}\left(\mathrm{CO}_{2}\right)$ from the sample surface. Finally, the sample was heated at a rate of $10^{\circ} \mathrm{C} / \mathrm{min}$ to the specified temperature in $\mathrm{Ar}$ flow $(30 \mathrm{~mL} / \mathrm{min})$, and the desorption temperature of $\mathrm{NH}_{3}\left(\mathrm{CO}_{2}\right)$ was detected using a thermal conductivity detector (TCD). The total surface acidity and basicity of the samples were determined from the TPD of $\mathrm{NH}_{3}$ and $\mathrm{CO}_{2}$, respectively.

The TGA of the catalysts was investigated on a Netzsch STA 4449 F3, which was used to measure the carbon deposition of the catalyst after reaction.

\subsection{Catalytic Performance Evaluation}

Vapour-phase selective $O$-methylation synthesis of guaiacol by catechol and methanol was performed in a self-made fixed-bed reactor at atmospheric pressure with a length of $750 \mathrm{~mm}$ and an inside diameter of $14 \mathrm{~mm}$ quartz tube. The catalyst evaluation system was shown in Figure 1. A 6 g catalyst (20-40 mesh) was taken and placed in a catalytic bed. Prior to the reaction, nitrogen was used to remove oxygen from the tube, the catalyst was heated at a rate of $10^{\circ} \mathrm{C} / \mathrm{min}$ in the meantime, and nitrogen purging was stopped until the catalyst was heated to a specified reaction temperature. Reaction liquid was transported into the reaction tube by advection pump. The products were analyzed with a gas chromatograph (Fuli gas chromatograph GC9790) equipped with a capillary column (SE-54) and were identified using known standards and GC-MS. Guaiacol is the main product and 1,2-dimethoxybenzene is the main byproduct. Concurrently, other byproducts are mainly further alkylates of the products as follows:
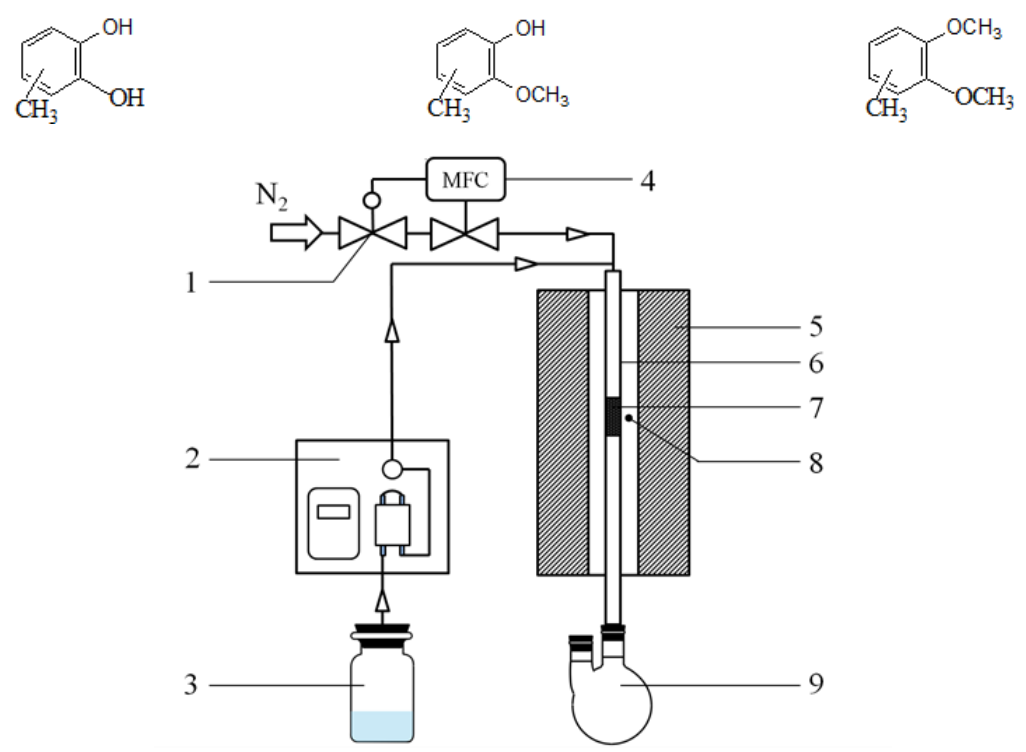

Figure 1. Diagram of catalyst evaluation system. 1. Stable-Flow valve; 2 . Advection pump; 3 . Reaction mixture; 4 . Mass flow controller; 5 . Tube furnace; 6 . Reaction tube; 7 . Catalyst bed; 8 . Thermoelectric couple; 9. Receiving flask. 
The conversion of catechol $\left(C_{\text {catechol }}\right)$, selectivity of guaiacol $\left(S_{\text {guaiacol }}\right)$, selectivity of 1,2dimethoxybenzene $\left(S_{1,2 \text {-dimethoxybenzene }}\right)$, selectivity of other byproducts $\left(S_{\text {other byproducts }}\right)$, and yield of guaiacol $\left(Y_{\text {catechol }}\right)$ were calculated using the normalization method, with catechol as the reference substance. The details are shown in Equations (1)-(5):

$$
\begin{gathered}
C_{\text {catechol }}=\frac{f_{1} A_{1}+f_{2} A_{2}+f_{3} A_{3}}{f_{1} A_{1}+f_{2} A_{2}+f_{3} A_{3}+A} \times 100 \% \\
S_{\text {guaiacol }}=\frac{f_{1} A_{1}}{f_{1} A_{1}+f_{2} A_{2}+f_{3} A_{3}} \times 100 \% \\
Y_{\text {guaiacol }}=C_{\text {catechol }} \times S_{\text {guaiacol }} \div 100 \\
S_{1,2-\text { Dimethoxybenzene }}=\frac{f_{2} A_{2}}{f_{1} A_{1}+f_{2} A_{2}+f_{3} A_{3}} \times 100 \% \\
S_{\text {other byproducts }}=\frac{f_{3} A_{3}}{f_{1} A_{1}+f_{2} A_{2}+f_{3} A_{3}} \times 100 \%
\end{gathered}
$$

where $f_{1}, f_{2}$, and $f_{3}$ represented the correction factor of guaiacol; 1,2-dimethoxybenzene; and other byproducts, respectively. In view of the similar properties and low content of these byproducts, we calculate the other byproducts as a whole. The calibration factor of 2-methoxy-6-methylphenol is used to calculate other byproducts, where $A, A_{1}, A_{2}$, and $A_{3}$ represent chromatographic peak areas of catechol; guaiacol; 1,2-dimethoxybenzene; and the sum of peak areas of all byproducts.

\section{Results and Discussion}

\subsection{Catalyst Characterization}

Figure 2 presents the XRD patterns of Al- $x \mathrm{P}-\mathrm{O}(x=0,0.25,0.05,0.75,1.00,1.10,1.15$, 1.20) catalysts, together with that of $\mathrm{Al}-1.1 \mathrm{P}-\mathrm{O}^{\mathrm{a}}$ for comparison. The Al-0P-O sample showed three strong diffraction peaks of $\gamma-\mathrm{Al}_{2} \mathrm{O}_{3}$ around $2 \theta=37^{\circ}, 46^{\circ}$, and $67^{\circ}$. When the $\mathrm{P} / \mathrm{Al}$ molar ratio increased to 0.25 , it was interesting to note that the diffraction peaks intensities of $\gamma-\mathrm{Al}_{2} \mathrm{O}_{3}$ decreased significantly, and a new weak and broad diffraction peak corresponding to amorphous aluminum phosphate around $2 \theta=24^{\circ}$ appeared $[22,30,31]$. No diffraction peaks assigned to $\mathrm{P}_{2} \mathrm{O}_{5}$ were observed. These results demonstrated that the addition of $\mathrm{P}$ resulted in forming amorphous aluminum phosphate rather than a mixture of $\mathrm{Al}_{2} \mathrm{O}_{3}$ and $\mathrm{P}_{2} \mathrm{O}_{5}$. With the increasing of the $\mathrm{P} / \mathrm{Al}$ molar ratio to 0.5 , the diffraction peak around $2 \theta=24^{\circ}$ was observed clearly. Concurrently, the diffraction peaks corresponding to $\gamma-\mathrm{Al}_{2} \mathrm{O}_{3}$ completely disappeared. With further increase of the P/Al molar ratio to 1.1, the intensity of aluminum phosphate diffraction peaks kept no obvious change. When the $\mathrm{P} / \mathrm{Al}$ molar ratio further increased to 1.15 , four sharp diffraction peaks assigned to aluminum phosphate around $2 \theta=20.4^{\circ}, 21.6^{\circ}, 23.2^{\circ}$, and $35.8^{\circ}$ were observed, corresponding to

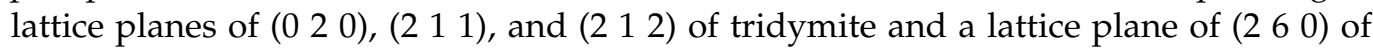
$\alpha$-cristobalite, respectively [32]. In addition, diffraction peaks of $\mathrm{NH}_{4} \mathrm{AlP}_{2} \mathrm{O}_{7}$ were also noticed around $2 \theta=29.8^{\circ}, 31.1^{\circ}$, and $38.7^{\circ}$. The intensity of $\mathrm{AlPO}_{4}$ crystalline phase and $\mathrm{NH}_{4} \mathrm{AlP}_{2} \mathrm{O}_{7}$ crystalline phase became stronger in the Al-1.20P-O sample than in Al-1.15PO. Table 1 displays the crystallite size of $\mathrm{AlPO}_{4}$ calculated using the Scherrer equation. $\mathrm{AlPO}_{4}$ crystallite sizes were $30.9 \mathrm{~nm}$ for the Al-1.15P-O and $34.3 \mathrm{~nm}$ for the Al-1.20P-O, respectively. These results suggest that $\mathrm{AlPO}_{4}$ crystalline phase and $\mathrm{NH}_{4} \mathrm{AlP}_{2} \mathrm{O}_{7}$ crystalline phase formed when the $\mathrm{P} / \mathrm{Al}$ molar ratio reached 1.15. Larger crystalline sizes are easier to form on $\mathrm{Al}-x \mathrm{P}-\mathrm{O}$ with higher $\mathrm{P} / \mathrm{Al}$ molar ratios. Compared with the $\mathrm{Al}-1.1 \mathrm{P}-\mathrm{O}$, the Al-1.1P-O $\mathrm{O}^{\mathrm{a}}$ sample showed distinct crystalline phases of $\mathrm{AlPO}_{4}$ and $\mathrm{NH}_{4} \mathrm{AlP}_{2} \mathrm{O}_{7}$. These results demonstrated that the presence of $\mathrm{P} 123$ in the precursor solutions could restrain the formation of crystalline phases in regard to $\mathrm{Al}$ and $\mathrm{P}$ species. 


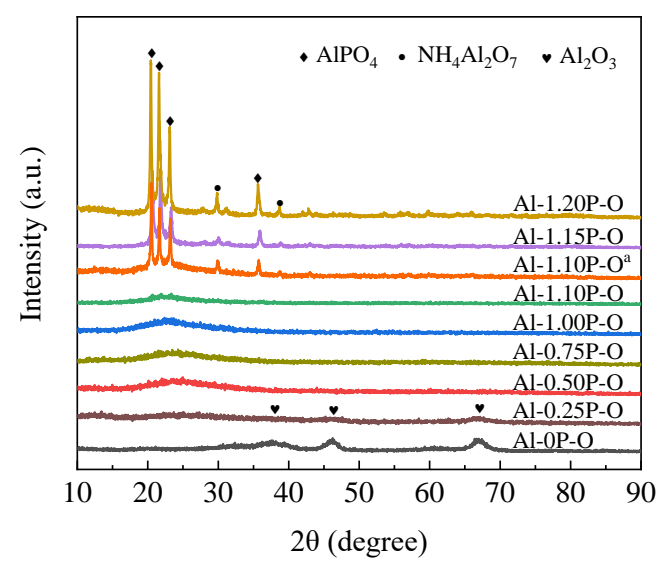

Figure 2. XRD patterns of $\mathrm{Al}-x \mathrm{P}-\mathrm{O}$ and $\mathrm{Al}-1.1 \mathrm{P}-\mathrm{O}^{\mathrm{a}}$ samples.

Table 1. The textural properties of Al- $x \mathrm{P}-\mathrm{O}$ and $\mathrm{Al}-1.1 \mathrm{P}-\mathrm{O}^{\mathrm{a}}$ samples.

\begin{tabular}{|c|c|c|c|c|c|c|}
\hline Catalysts & $\begin{array}{c}\mathrm{AlPO}_{4} \text { Particle } \\
\text { Size }(\mathrm{nm}) \text { by XRD }\end{array}$ & $S_{\text {BET }}\left(m^{2} \cdot g^{-1}\right)$ & $V_{P}\left(\mathrm{~cm}^{3} \cdot \mathrm{g}^{-1}\right)$ & $\mathrm{D}_{\mathrm{a}}(\mathrm{nm})$ & $\begin{array}{l}\text { Total Acidity } \\
\left(\mu \mathrm{mol} \cdot \mathrm{g}^{-1}\right)\end{array}$ & $\begin{array}{c}\text { Total Basicity } \\
\left(\mu \mathrm{mol} \cdot \mathrm{g}^{-1}\right)\end{array}$ \\
\hline Al-0P-O & - & 249 & 1.19 & 14.9 & 27.14 & 34.06 \\
\hline Al-0.25P-O & - & 319 & 2.03 & 21.6 & 40.45 & 32.99 \\
\hline Al-0.50P-O & - & 273 & 1.72 & 23.7 & 56.16 & 28.75 \\
\hline Al-0.75P-O & - & 220 & 1.40 & 22.6 & 82.63 & 46.63 \\
\hline Al-1.00P-O & - & 176 & 1.25 & 22.9 & 56.65 & 35.70 \\
\hline Al-1.10P-O & - & 147 & 1.08 & 23.9 & 53.44 & 21.61 \\
\hline Al-1.10P-O & 37.8 & 99 & 0.47 & 15.2 & 21.96 & 13.17 \\
\hline Al-1.15P-O & 30.9 & 30 & 0.10 & 14.2 & 5.76 & 4.15 \\
\hline Al-1.20P-O & 34.3 & 23 & 0.05 & 10.7 & 4.20 & 3.79 \\
\hline
\end{tabular}

The basic textural properties of the prepared Al-P-O samples are summarized in Table 1. It could be seen that compared with Al-0P-O, the prepared Al-0.25P-O sample exhibited an increase in specific surface area, pore volume, and average pore size. When the $\mathrm{P} / \mathrm{Al}$ molar ratio increased from 0.25 to 1.10 , a decrease in the surface area and pore volume was observed, but the pore sizes had little change. In further increasing the P/Al molar ratio to 1.15 and 1.20, the specific surface area, pore volume and average pore size decreased dramatically. For instance, the Al-0.25P-O sample showed a specific surface area $\left(S_{\mathrm{BET}}\right)$ of $319 \mathrm{~m}^{2} \mathrm{~g}^{-1}$, a pore volume $\left(V_{\mathrm{P}}\right)$ of $2.03 \mathrm{~cm}^{3} \mathrm{~g}^{-1}$, and an average pore size $\left(D_{\mathrm{a}}\right)$ of $21.6 \mathrm{~nm}$, whereas those of the Al-1.10P-O were $147 \mathrm{~m}^{2} \mathrm{~g}^{-1}, 1.08 \mathrm{~cm}^{3} \mathrm{~g}^{-1}$, and $23.9 \mathrm{~nm}$, respectively. However, Al-1.15P-O only had a $S_{\mathrm{BET}}$ of $30 \mathrm{~m}^{2} \mathrm{~g}^{-1}, V_{\mathrm{P}}$ of $0.10 \mathrm{~cm}^{3} \mathrm{~g}^{-1}$ and $D_{\mathrm{a}}$ of $14.2 \mathrm{~nm}$. Compared with the Al-1.1P-O sample, the Al-1.1P-O $\mathrm{O}^{\mathrm{a}}$ sample-prepared absence of $\mathrm{P} 123$ showed smaller specific surface area, pore volume, and average pore size. Combined with $X R D$ results, it can be speculated that $\mathrm{P}$ addition can bond with $\mathrm{Al}^{3+}$ to form aluminum phosphate, further altering the basic textural properties of the $\mathrm{Al}-x \mathrm{P}-\mathrm{O}$ samples. Higher P/Al molar ratios decreased specific surface area, pore volume, and average pore size. The existence of P123 favors a higher specific surface area, pore volume, and average pore size.

The microscopic morphology of Al- $x \mathrm{P}-\mathrm{O}$ samples are showed in Figure 3. It can be clearly observed that while the $\mathrm{P} / \mathrm{Al}$ ratio was less than or equal to 1.1, the samples had a wormlike structure, and the microscopic morphology of samples did not change significantly with the increase of the $\mathrm{P} / \mathrm{Al}$ ratio. While the $\mathrm{P} / \mathrm{Al}$ ratio was higher than 1.1, the particles of different sizes were deposited on the surface of the sample to form the accumulation holes, and the grain size increased prominently with the increase of the $\mathrm{P} / \mathrm{Al}$ molar ratio. These indicated that the samples with a higher $\mathrm{P} / \mathrm{Al}$ ratio $(x>1.1)$ were easy to condense to particles with crystal phase structure, leading to a prominent decrease in 
the specific surface area of samples, which was consistent with XRD and BET results. As for the Al-1.1P-Oa sample, a dense and less porous morphology was observed.
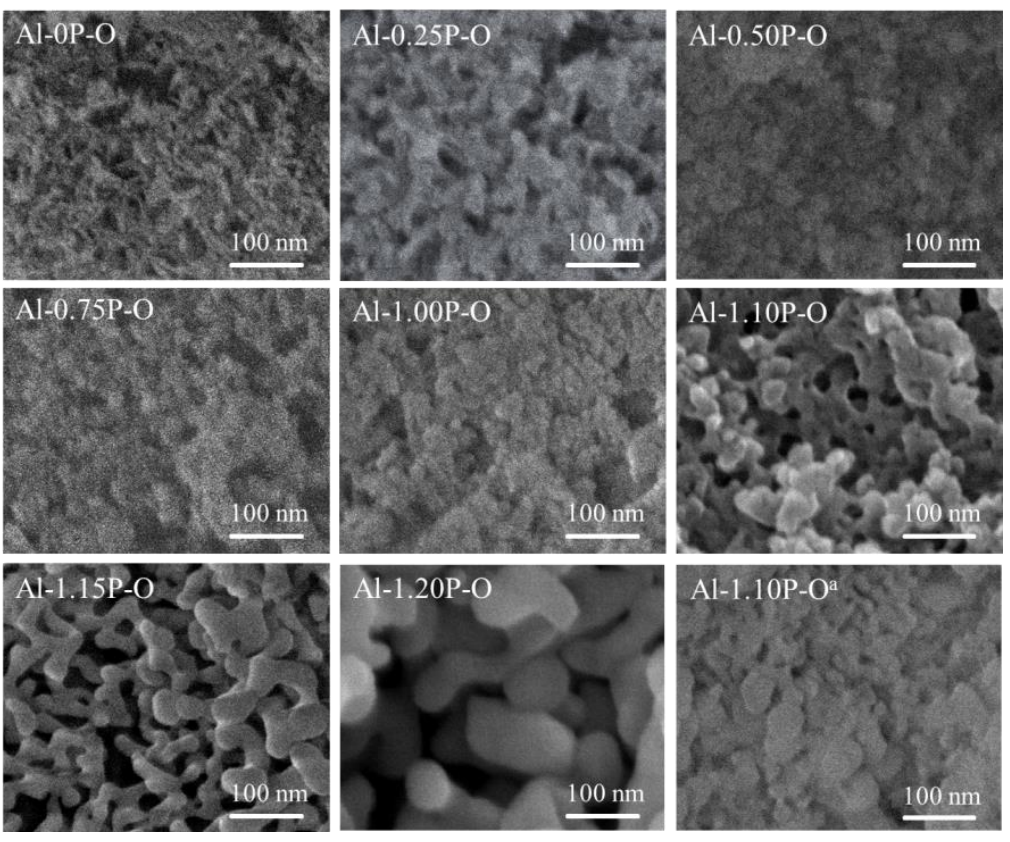

Figure 3. SEM images of $\mathrm{Al}-x \mathrm{P}-\mathrm{O}$ and $\mathrm{Al}-1.1 \mathrm{P}-\mathrm{O}^{\mathrm{a}}$ samples.

FT-IR spectra of Al- $x \mathrm{P}-\mathrm{O}$ samples are presented in Figure 4. All the tested samples had obvious vibration signals at $3470 \mathrm{~cm}^{-1}$ and $1634 \mathrm{~cm}^{-1}$, which were attributed to the stretching vibration the $\mathrm{O}-\mathrm{H}$ bond and bending vibration of physically adsorbed water, respectively [24,33-35]. All samples except Al-OP-O had vibration signals at $1139 \mathrm{~cm}^{-1}$, $730 \mathrm{~cm}^{-1}$ and $490 \mathrm{~cm}^{-1}$. The vibration signal at $1139 \mathrm{~cm}^{-1}$ could belong to the asymmetric stretching vibration of the $\mathrm{P}-\mathrm{O}$ bond in the $\left(\mathrm{PO}_{4}\right)^{3-}$ tetrahedron. The vibration signal located around $490 \mathrm{~cm}^{-1}$ was attributed to the bending vibration of O-P-O in the $\left(\mathrm{PO}_{4}\right)^{3-}$ tetrahedron. The vibration signal around $730 \mathrm{~cm}^{-1}$ was assigned to the vibration of Al$\mathrm{O}$ bond combined with P-O bond [27,31,36,37]. When $x \leq 1.1, \mathrm{Al}-x \mathrm{P}-\mathrm{O}$ samples had a weak vibration signal near $730 \mathrm{~cm}^{-1}$, this indicated that Al- $x \mathrm{P}-\mathrm{O}$ samples $(x<1.1)$ had an amorphous aluminum phosphate structure instead of a simple mixture of $\mathrm{Al}_{2} \mathrm{O}_{3}$ and $\mathrm{P}_{2} \mathrm{O}_{5}$. When $x>1.1$, the vibration signal of the Al- $x \mathrm{P}-\mathrm{O}$ samples at $730 \mathrm{~cm}^{-1}$ was significantly enhanced. This strong vibration signal should be caused by the formation of crystalline aluminum phosphate phase, which is consistent with the results of XRD characterization.

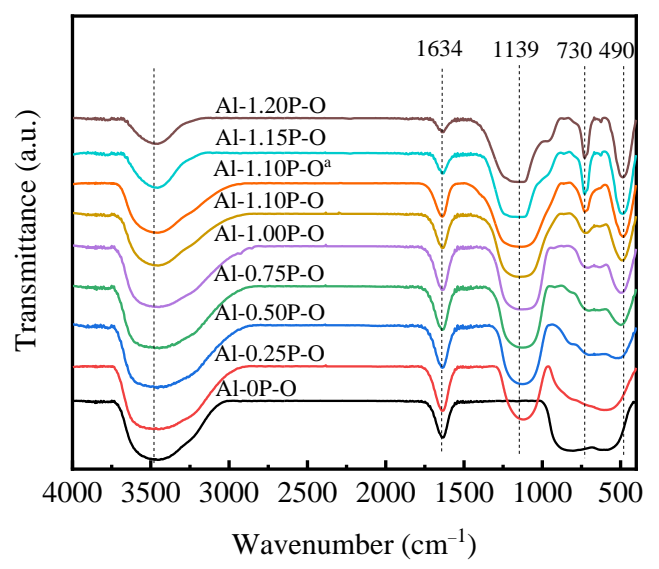

Figure 4. FT-IR spectra of $\mathrm{Al}-x \mathrm{P}-\mathrm{O}$ and $\mathrm{Al}-1.1 \mathrm{P}-\mathrm{O}^{\mathrm{a}}$ samples. 
$\mathrm{NH}_{3}$-TPD profiles and surface acidic and basic parameters of $\mathrm{Al}-x \mathrm{P}-\mathrm{O}$ and $\mathrm{Al}-1.1 \mathrm{P}-$ $\mathrm{O}^{\mathrm{a}}$ samples are displayed in Figure 5a and Table 1. All samples had a desorption peak between 100 and $250{ }^{\circ} \mathrm{C}$, indicating the existence of weak acid sites [38]. The desorption peaks shifted to lower $\mathrm{NH}_{3}$ desorption temperature with the increasing $\mathrm{P} / \mathrm{Al}$ molar ratio, indicating that the addition of $\mathrm{P}$ weakened the strength of the acid site. The area of the $\mathrm{NH}_{3}$ desorption peak increased when the $\mathrm{P} / \mathrm{Al}$ molar ratio increased from 0 to 0.75 . With the increase of the $\mathrm{P} / \mathrm{Al}$ molar ratio to 1.10, the area of the $\mathrm{NH}_{3}$ desorption peak decreased slightly. However, when the $\mathrm{P} / \mathrm{Al}$ molar ratio further increased to 1.15 and 1.2, a sudden decrease of the area of the $\mathrm{NH}_{3}$ desorption peak appeared, indicating that the number of acid sites of catalysts with higher P/Al molar ratio $(x \geq 1.15)$ was very low. It could be speculated that the $\mathrm{P}-\mathrm{OH}$ group was the main source of the weak acid center. The catalyst with the higher $\mathrm{P} / \mathrm{Al}$ molar ratio $(\mathrm{P} / \mathrm{Al}>1.1)$ eased the formation of aluminum phosphate crystal phase, resulting in a low number of acid centers. Compared with the Al-1.1P-O sample, Al-1.1P-O ${ }^{a}$ had a lower $\mathrm{NH}_{3}$ desorption temperature and a smaller area of $\mathrm{NH}_{3}$ desorption peak, proving that $\mathrm{P} 123$ addition could boost the formation of stronger acid sites.

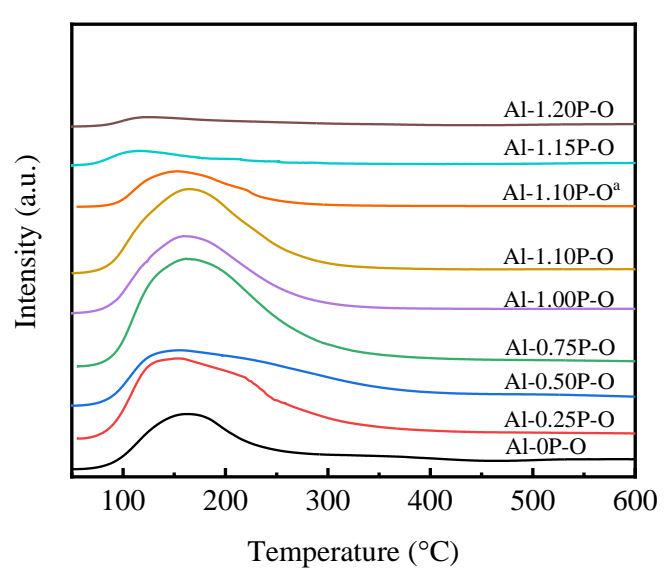

(a)

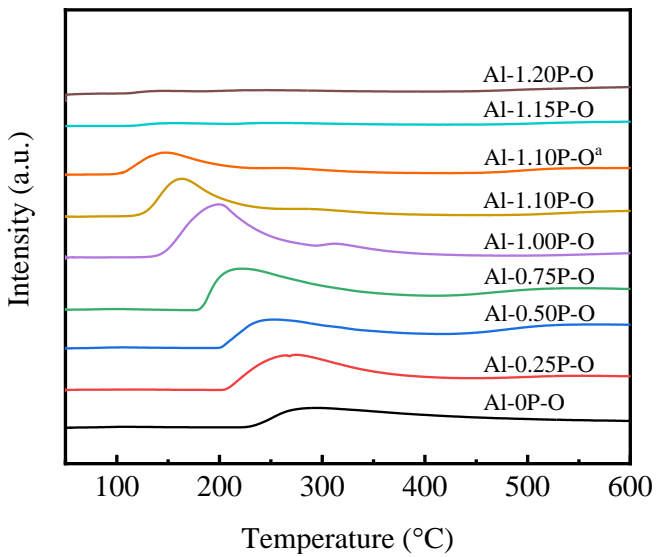

(b)

Figure 5. (a) $\mathrm{NH}_{3}-\mathrm{TPD}$ and (b) $\mathrm{CO}_{2}-\mathrm{TPD}$ profiles of $\mathrm{Al}-x \mathrm{P}-\mathrm{O}$ and $\mathrm{Al}-1.1 \mathrm{P}-\mathrm{O}^{\mathrm{a}}$ samples.

$\mathrm{CO}_{2}$-TPD profiles of Al- $x \mathrm{P}-\mathrm{O}$ samples are shown in Figure 5b. All the samples gave a broad $\mathrm{CO}_{2}$ desorption temperature in the range of $100-350{ }^{\circ} \mathrm{C}$. The desorption peak in the ranges of $100-200{ }^{\circ} \mathrm{C}$ and $200-350^{\circ} \mathrm{C}$ were assigned to weak basic site and mediumstrength basic site [27]. The $\mathrm{CO}_{2}$ desorption peaks shifted towards low temperature with the increasing $\mathrm{P} / \mathrm{Al}$ molar ratio, indicating that the strength of the basic sites gradually decreased. However, the area of the $\mathrm{CO}_{2}$ desorption peak for the catalysts with a $\mathrm{P} / \mathrm{Al}$ molar ratio between 0.25 and 1.1 showed no obvious changes, whereas the area of the $\mathrm{CO}_{2}$ desorption peak decreased significantly in $\mathrm{Al}-x \mathrm{P}-\mathrm{O}$ samples $(\mathrm{P} / \mathrm{Al}>1.1)$. In the case of Al-1.1P-O ${ }^{\mathrm{a}}$, a lower $\mathrm{CO}_{2}$ desorption temperature and a smaller area of the $\mathrm{CO}_{2}$ desorption peak than those of the Al-1.1P-O sample indicate that P123 addition could promote the formation of stronger basic sites.

\subsection{Catalytic Performance Evaluation}

The catalytic performance of Al- $x \mathrm{P}-\mathrm{O}$ catalysts for vapour-phase selective $O$-methylation of catechol and methanol to guaiacol was investigated under optimized reaction conditions, and the results are listed in Table 2. The $\mathrm{P} / \mathrm{Al}$ molar ratio had a significant influence on the catalyst activity and selectivity. The Al-0P-O showed catechol conversion of $45.1 \%$. With the addition of $\mathrm{P}$, the catechol conversion gradually increased and showed a maximum value of $76.8 \%$ at $x=0.75$. As the $\mathrm{P} / \mathrm{Al}$ molar ratio increased further, the catalytic activity started to decrease, and the catechol conversion decreased to $58.0 \%$ at $x=1.10$, further increasing the $\mathrm{P} / \mathrm{Al}$ molar ratio to $x=1.15$, only a $25.2 \%$ conversion. These results were in 
accordance with the number of acid sites measured by $\mathrm{NH}_{3}$-TPD shown in Figure 5 . The low catechol conversion was mainly due to scarcity of acidity sites. Guaiacol selectivity firstly increased with the increasing $\mathrm{P} / \mathrm{Al}$ molar ratio in the range of $0-1.1$, and then increased slightly at $97.6 \%$ and $99.4 \%$ for Al-1.1P-O and Al-1.2P-O. Comparatively, Al-1.1P$\mathrm{O}^{\mathrm{a}}$ catalysts without $\mathrm{P} 123$ showed lower catechol conversion of $43.6 \%$ compared to Al-1.1P$\mathrm{O}$ (catechol conversion of $58.0 \%$ ) but also showed a high selectivity of $97.7 \%$. Combined with the characterization results, the Al- $x \mathrm{P}-\mathrm{O}$ catalysts which possessed weak acid-base sites exhibited excellent guaiacol selectivity with higher catalytic activity. Although the Al$0.75 \mathrm{P}-\mathrm{O}$ catalyst had the highest yield, it was worth noting that multiple byproducts were generated, including 3-methylcatechol; 2-methoxy-6-methylphenol; 2,3-dimethoxytoluene; etc. Poor selectivity certainly would increase the cost of product separation. Therefore, Al-1.10P-O catalysts, which exhibited a higher selectivity of $97.6 \%$ with a comparatively higher conversion of $58.0 \%$, was considered to be chosen for further stability study.

Table 2. Catalytic performance of $\mathrm{Al}-x \mathrm{P}-\mathrm{O}$ and $\mathrm{Al}-1.1 \mathrm{P}-\mathrm{O}^{\mathrm{a}}$ catalysts.

\begin{tabular}{|c|c|c|c|c|c|}
\hline \multirow{2}{*}{ Catalysts } & \multirow{2}{*}{ Conversion of Catechol (\%) } & \multicolumn{3}{|c|}{ Selectivity (\%) } & \multirow{2}{*}{ Yield (\%) } \\
\hline & & Guaiacol & 1,2-Dimethoxybenzene & Others & \\
\hline Al-0P-O & 45.1 & 77.4 & 2.1 & 20.5 & 34.9 \\
\hline Al-0.25P-O & 64.1 & 83.6 & 4.4 & 12.0 & 53.6 \\
\hline Al-0.50P-O & 66.5 & 83.1 & 5.0 & 11.9 & 55.3 \\
\hline Al-0.75P-O & 76.8 & 89.5 & 3.1 & 7.4 & 68.7 \\
\hline Al-1.00P-O & 63.1 & 92.4 & 2.1 & 5.5 & 58.3 \\
\hline Al-1.10P-O & 58.0 & 97.6 & 2.3 & 0.1 & 56.6 \\
\hline Al-1.10P-O & 43.6 & 97.7 & 2.2 & 0.1 & 42.6 \\
\hline Al-1.15P-O & 25.2 & 99.3 & 0.7 & 0 & 25.0 \\
\hline Al-1.20P-O & 22.9 & 99.4 & 0.6 & 0 & 22.8 \\
\hline
\end{tabular}

Reaction conditions: $\mathrm{m}_{\mathrm{cat}}=6 \mathrm{~g}$, Reaction temperature $=275^{\circ} \mathrm{C}, \mathrm{LHSV}=0.6 \mathrm{~h}^{-1}$, methanol $/$ catechol $=6 \mathrm{~mol}$, reaction time $=6 \mathrm{~h}$.

The catalytic stability test was conducted on the Al-1.1P-O catalyst under the reaction conditions $\mathrm{m}_{\text {cat }}=6 \mathrm{~g}$, Reaction temperature $=275^{\circ} \mathrm{C}, \mathrm{LHSV}=0.6 \mathrm{~h}^{-1}$, methanol $/$ catechol $=6 \mathrm{~mol}$. To understand the effect of $\mathrm{P} 123$ on the stability of the catalyst, a stability test was also carried out on an Al-1.10P-O ${ }^{\mathrm{a}}$ sample under the same conditions. As can be seen in Figure 6, the addition of P123 had a significant influence on catalytic activity and selectivity. For the Al-1.1P-O catalyst, guaiacol selectivity was constant at ca. 97.6\% during the $300-\mathrm{h}$ reaction period. The conversion of catechol decreased slightly from ca. $58.0 \%$ to ca. $53.0 \%$ in the initial stage of $50 \mathrm{~h}$, and kept unchanged during the following period, showing very high catalytic stability. In the case of $\mathrm{Al}-1.10 \mathrm{P}-\mathrm{O}^{\mathrm{a}}$, catechol conversion and guaiacol selectivity decrease from ca. $43.6 \%$ and ca. $97.7 \%$ to ca. $18.0 \%$ and ca. $95.9 \%$, respectively, during the 100-h reaction time.

It has been established that carbon deposition is mainly responsible for the deactivation of acid/base catalysts. Thus, TG was employed to investigate the amount of carbon depositions on the spent Al-1.1P-O catalyst after $300 \mathrm{~h}$ (denoted as Al-1.1P-O-S300) and the spent $\mathrm{Al}-1.10 \mathrm{P}-\mathrm{O}^{\mathrm{a}}$ catalyst (denoted as $\mathrm{Al}-1.1 \mathrm{P}-\mathrm{O}^{\mathrm{a}}-\mathrm{S} 100$ ) after $100 \mathrm{~h}$ for $\mathrm{O}$-methylation of catechol. The samples exhibited a first weight loss in the low temperature range of ca. $50-250{ }^{\circ} \mathrm{C}$, corresponding to physically adsorbed commands. This process was followed by the removal of the carbon deposited on the catalyst surface in the range of ca. $250-650{ }^{\circ} \mathrm{C}$, which was used to quantify the amount of deposited carbon. When the temperature reached $650{ }^{\circ} \mathrm{C}$, negligible weight loss was detected. The results of the amounts of carbon depositions are given in Table 3. Only trace amounts of carbon were deposited in the Al-1.1P-O catalyst. The average carbon depositions per hour on $\mathrm{Al}-1.1 \mathrm{P}-\mathrm{O}^{\mathrm{a}}-\mathrm{S} 100$ were three times as high as those on Al-1.1P-O, indicating that the addition of P123 was indeed beneficial to inhibit and eliminate the carbon deposition. Combined with the catalyst characterization results, we speculated that smaller pore volume suppressed the large molecular size byproducts detaching from the catalyst surface. As the reaction went on, 
the active center of the reaction was gradually occupied, leading to the gradual decline of catechol conversion.

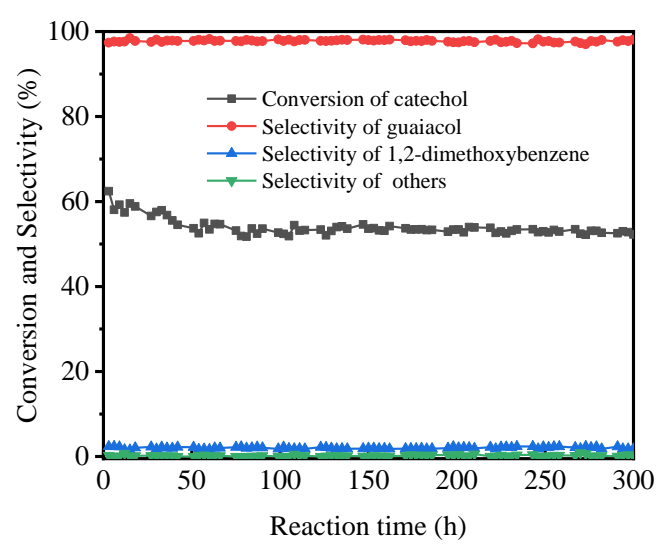

(a)

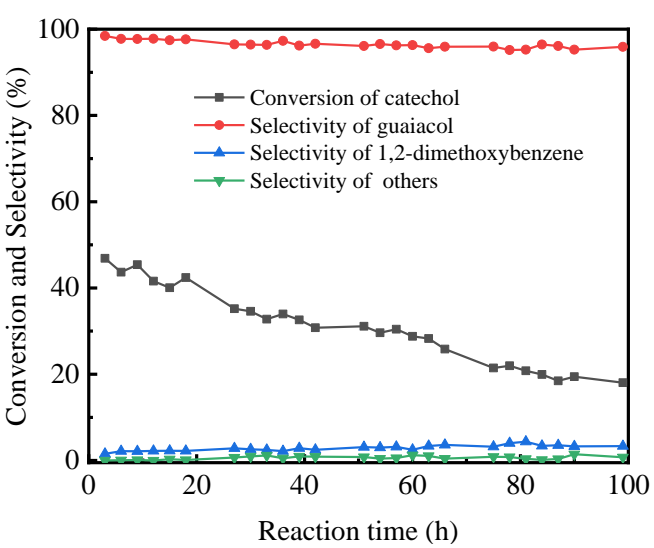

(b)

Figure 6. Stability test of (a) Al-1.1P-O catalyst and (b) Al-1.1P-O . Reaction conditions: $\mathrm{m}_{\text {cat }}=6 \mathrm{~g}$, Reaction temperature $=275^{\circ} \mathrm{C}$, LHSV $=0.6 \mathrm{~h}^{-1}$, methanol $/$ catechol $=6 \mathrm{~mol}$.

Table 3. The textural properties of $\mathrm{Al}-x \mathrm{P}-\mathrm{O}$ and $\mathrm{Al}-1.1 \mathrm{P}-\mathrm{O}^{\mathrm{a}}$ samples.

\begin{tabular}{cccc}
\hline Catalysts & Reaction Time (h) & Carbon Amount by TG (mg.g $\mathbf{c a t}^{-\mathbf{1})}$ & $\begin{array}{c}\text { Average Carbon Depositions per Hour } \\
\left(\mathbf{m g} \cdot \mathbf{g}_{\mathbf{c a t}} \mathbf{- 1} \cdot \mathbf{h}^{-\mathbf{1})}\right.\end{array}$ \\
\hline Al-1.1P-O-S300 & 300 & 38 & 0.13 \\
Al-1.1P-O $-\mathrm{S} 100$ & 100 & 45 & 0.45 \\
\hline
\end{tabular}

\section{Conclusions}

In summary, $\mathrm{Al}-x \mathrm{P}-\mathrm{O}$ samples were prepared through a P123-assisted one-pot method and used for $\mathrm{O}$-methylation of catechol and methanol to produce guaiacol. $\mathrm{Al}$ and $\mathrm{P}$ species were mainly in the aluminum phosphate phase. When $x \leq 1.1$, the aluminum phosphate phase was amorphous, and the aluminum phosphate in crystalline phase with large particle size formed in Al- $x \mathrm{P}-\mathrm{O}$ samples with higher $\mathrm{P} / \mathrm{Al}$ molar ratios $(x>1.1)$. P123 addition could inhibit the formation of aluminum phosphate crystal phase to a certain extent. P/Al molar ratio and P123 addition had a significant influence on crystal structure, acid-base sites, and basic textural properties. All prepared samples showed weak acid-base sites, which were beneficial to producing guaiacol with catechol and methanol. The Al-1.1P-O catalyst prepared with P123-assistance exhibited superior catalytic performances with ca. $58.0 \%$ catechol conversion, ca. $97.6 \%$ guaiacol selectivity, and $300 \mathrm{~h}$ stability.

Author Contributions: Conceptualization, X.Z. and X.W.; methodology, D.X., J.R. and X.Z.; validation, D.X., J.R. and X.Z.; formal analysis, D.X., S.Y. and X.W.; investigation, D.X., J.R., X.Z. and X.S.; data curation, D.X., J.R., X.Z. and X.W.; writing—original draft preparation, D.X. and X.Z.; writing - review and editing, X.Z. and X.S.; supervision, X.Z. and X.W.; project administration, X.Z. and X.W.; funding acquisition, X.W. All authors have read and agreed to the published version of the manuscript.

Funding: This research received no external funding.

Institutional Review Board Statement: Not applicable.

Informed Consent Statement: Not applicable.

Data Availability Statement: The data presented in this study are available on request from the corresponding author.

Conflicts of Interest: The authors declare no conflict of interest. 


\section{References}

1. Yang, L.; Zhou, W.; Seshan, K.; Li, Y. Green and efficient synthesis route of catechol from guaiacol. J. Mol. Catal. A: Chem. 2013, 368, 61-65. [CrossRef]

2. Tran, N.T.; Uemura, Y.; Chowdhury, S.; Ramli, A. Vapor-phase hydrodeoxygenation of guaiacol on Al-MCM-41 supported Ni and Co catalysts. Appl. Catal. A: Gen. 2016, 512, 93-100. [CrossRef]

3. Mao, J.B.; Zhou, J.X.; Xia, Z.; Wang, Z.G.; Xu, Z.W.; Xu, W.J.; Yan, P.F.; Liu, K.R.; Guo, X.W.; Zhang, Z.C. Anatase TiO 2 activated by gold nanoparticles for selective hydrodeoxygenation of guaiacol to phenolics. ACS Catal. 2017, 7, 695-705. [CrossRef]

4. Nair, V.; Vinu, R. Production of guaiacols via catalytic fast pyrolysis of alkali lignin using titania, zirconia and ceria. J. Anal. Appl. Pyrolysis 2016, 119, 31-39. [CrossRef]

5. Kakhlon, O.; Ferreira, I.; Solmesky, L.J.; Khazanov, N.; Lossos, A.; Alvarez, R.; Yetil, D.; Pampou, S.; Weil, M.; Senderowitz, H.; et al. Guaiacol as a drug candidate for treating adult polyglucosan body disease. JCI Insight 2018, 3. [CrossRef] [PubMed]

6. Sánchez-Gómez, R.; Torregrosa, L.; Zalacain, A.; Ojeda, H.; Bouckenooghe, V.; Schneider, R.; Alonso, G.L.; Salinas, M.R. Behavior of glycosylated aroma precursors in Microvine fruits after guaiacol foliar application. Sci. Hortic. 2019, 246, e1-e8. [CrossRef]

7. Pardo-Garcia, A.I.; Wilkinson, K.L.; Culbert, J.A.; Lloyd, N.D.; Alonso, G.L.; Salinas, M.R. Accumulation of guaiacol glycoconjugates in fruit, leaves and shoots of Vitis vinifera cv. Monastrell following foliar applications of guaiacol or oak extract to grapevines. Food Chem. 2017, 217, 782-789. [CrossRef] [PubMed]

8. Llevot, A.; Grau, E.; Carlotti, S.; Grelier, S.; Cramail, H. From lignin-derived aromatic compounds to novel biobased polymers. Macromol. Rapid Commun. 2015, 37, 9-28. [CrossRef]

9. Mao, H.; Zhang, C.; Meng, T.; Wang, H.; Hu, X.; Xiao, Z.; Wang, C.; Liu, J. Effect and mechanism of aluminum(III) For guaiacol-glyoxylic acid condensation reaction in vanillin production. ACS Omega 2020, 5, 24526-24536. [CrossRef]

10. García-Bofill, M.; Sutton, P.W.; Guillén, M.; Álvaro, G. Enzymatic synthesis of vanillin catalysed by an eugenol oxidase. Appl. Catal. A: Gen. 2019, 582, 117117. [CrossRef]

11. Zhao, X.; Zhang, Y.; Cheng, Y.; Sun, H.; Bai, S.; Li, C. Identifying environmental hotspots and improvement strategies of vanillin production with life cycle assessment. Sci. Total. Environ. 2021, 769, 144771. [CrossRef]

12. Navaruckiene, A.; Bridziuviene, D.; Raudoniene, V.; Rainosalo, E.; Ostrauskaite, J. Influence of vanillin acrylate-based resin composition on resin photocuring kinetics and antimicrobial properties of the resulting polymers. Materials 2021, 14, 653. [CrossRef]

13. Bal, R.; Tope, B.B.; Sivasanker, S. Vapour phase O-methylation of dihydroxy benzenes with methanol over cesium-loaded silica, a solid base. J. Mol. Catal. A Chem. 2002, 181, 161-171. [CrossRef]

14. Vishwanathan, V.; Balakrishna, G.; Rajesh, B.; Jayasri, V.; Sikhwivhilu, L.M.; Coville, N.J. Alkylation of catechol with methanol to give guaiacol over sulphate-modified zirconia solid acid catalysts: The influence of structural modification of zirconia on catalytic performance. Catal. Commun. 2008, 9, 2422-2427. [CrossRef]

15. Fu, Y.; Baba, T.; Ono, Y. Vapor-phase reactions of catechol with dimethyl carbonate. Part II. Selective synthesis of guaiacol over alumina loaded with alkali hydroxide. Appl. Catal. A: Gen. 1998, 166, 425-430. [CrossRef]

16. Jafari, A.A.; Khodadadi, A.A.; Mortazavi, Y. Vapor-phase selective O-alkylation of catechol with methanol over lanthanum phosphate and its modified catalysts with Ti and Cs. J. Mol. Catal. A: Chem. 2013, 372, 79-83. [CrossRef]

17. Zhu, X.; Li, X.; Zou, X.; Wang, Y.; Jia, M.; Zhang, W. Supported ammonium metatungstate as highly efficient catalysts for the vapour-phase $O$-methylation of catechol with methanol. Catal. Commun. 2006, 7, 579-582. [CrossRef]

18. Jyothi, T.; Raja, T.; Talawar, M.; Rao, B. Selective O-methylation of catechol using dimethyl carbonate over calcined Mg Al hydrotalcites. Appl. Catal. A: Gen. 2001, 211, 41-46. [CrossRef]

19. Lui, M.Y.; Lokare, K.S.; Hemming, E.; Stanley, J.N.G.; Perosa, A.; Selva, M.; Masters, A.F.; Maschmeyer, T. Microwave-assisted methylation of dihydroxybenzene derivatives with dimethyl carbonate. RSC Adv. 2016, 6, 58443-58451. [CrossRef]

20. Kabra, S.K.; Huuhtanen, M.; Keiski, R.L.; Yadav, G.D. Selectivity engineering of $O$-methylation of hydroxybenzenes with dimethyl carbonate using ionic liquid as catalyst. React. Chem. Eng. 2016, 1, 330-339. [CrossRef]

21. Vijayaraj, M.; Gopinath, C. Selective production of methoxyphenols from dihydroxybenzenes on alkali metal ion-loaded MgO. J. Catal. 2006, 243, 376-388. [CrossRef]

22. Liao, X.Z.; Zhou, Z.; Wang, Z.L.; Zou, X.J.; Liu, G.; Jia, M.J.; Zhang, W.X. Preformed precursor of microporous alumino-phosphate coating on mesoporous SBA-15: Synthesis, characterization, and catalytic property for selective O-methylation of catechol. J. Colliod Interface Sci. 2007, 308, 176-181. [CrossRef] [PubMed]

23. Luque, R.; Campelo, J.M.; Conesa, T.D.; Luna, D.; Marinas, J.M.; Romero, A.A. Catechol O-methylation with dimethyl car-bonate over different acid-base catalysts. N. J. Chem. 2006, 30, 1228-1234. [CrossRef]

24. Mao, H.F.; Li, X.L.; Xu, F.; Xiao, Z.B.; Zhang, W.X.; Meng, T. Vapour-phase selective O-methylation of catechol with methanol over metal phosphate catalysts. Catalysts 2021, 11, 531. [CrossRef]

25. Li, X.M.; Zhang, W.X.; Liu, G.; Jiang, L.; Zhu, X.M.; Pan, C.L.; Jiang, D.Z.; Tang, A.Q. Effect of the P/Al ratio of Al-P-O on the catalytic activity of $O$-methylation of catechol with methanol. React. Kinet. Catal. Lett. 2003, 79, 365-371. [CrossRef]

26. Zhu, X.M.; Li, X.M.; Jia, M.J.; Liu, G.; Zhang, W.X.; Jiang, D.Z. Vapour-phase selective O-methylation of catechol with methanol over Ti-containing aluminium phosphate catalysts. Appl. Catal. A: Gen. 2005, 282, 155-161. [CrossRef] 
27. Liu, G.; Wang, Z.L.; Jia, M.J.; Zou, X.J.; Zhu, X.M.; Zhang, W.X.; Jiang, D.Z. Thermally stable amorphous mesoporous aluminophosphates with controllable P/Al ratio: Synthesis, characterization, and catalytic performance for selective O-methylation of catechol. J. Phys. Chem. B 2006, 110, 16953-16960. [CrossRef]

28. Yang, L.; Seshan, K.; Li, Y. Transetherification of guaiacol to o-ethoxyphenol with gamma $\mathrm{Al}_{2} \mathrm{O}_{3}$ as a catalyst in supercritical ethanol. Catal. Commun. 2012, 30, 36-39. [CrossRef]

29. Fu, Z.H.; Yu, Y.; Yin, D.L.; Xu, Y.Z.; Liu, H.P.; Liao, H.Y.; Xu, Q.; Tan, F.Q.; Wang, J. Vapor-phase highly selective O-methylation of catechol with methanol over $\mathrm{ZnCl}_{2}$ modified gamma- $\mathrm{Al}_{2} \mathrm{O}_{3}$ catalysts. J. Mol. Catal. A Chem. 2005, 232, 69-75. [CrossRef]

30. Vishwanathan, V.; Raghavan, K.V.; Ndou, S.; Sikhwivhilu, L.; Plint, N.; Coville, N.J. Evidence for weak base site participation in the vapour phase methylation of catechol over solid base catalysts. Chem. Commun. 2001, 893-894. [CrossRef]

31. Harish, N.; Kathyayini, N.; Nagaraju, N. Studies on the catalytic activity of mesoporous alumina-aluminophosphate $\left(\mathrm{Al}_{2} \mathrm{O}_{3}-\right.$ $\mathrm{AlPO}_{4}$ ) materials in the synthesis of $\mathrm{NN}^{\prime}$-diphenyl urea. React. Kinet. Mech. Cat. 2018, 125, 937-949. [CrossRef]

32. Campelo, J.M.; Jaraba, M.; Luna, D.; Luque, R.; Marinas, A.J.M.; Romero, A.A.; Navío, J.A.; Macias, M. Effect of phosphate precursor and organic additives on the structural and catalytic properties of amorphous mesoporous alpo4materials. Chem. Mater. 2003, 15, 3352-3364. [CrossRef]

33. Liao, Y.; Li, F.; Dai, X.; Zhao, N.; Xiao, F. Solid base catalysts derived from Ca-M-Al (M = Mg, La, Ce, Y) layered double hydroxides for dimethyl carbonate synthesis by transesterification of methanol with propylene carbonate. Chin. J. Catal. 2017, 38, 1860-1869. [CrossRef]

34. Fan, Y.; Zhang, M.; Shangguan, L. Synthesis of a novel and salt sensitive superabsorbent hydrogel using soybean dregs by UV-irradiation. Materials 2018, 11, 2198. [CrossRef]

35. Seesanong, S.; Boonchom, B.; Chaiseeda, K.; Boonmee, W.; Laohavisuti, N. Conversion of bivalve shells to monocalcium and tricalcium phosphates: An approach to recycle seafoodwastes. Materials 2021, 14, 4395. [CrossRef]

36. Wang, H.F.; Wang, Y.Y.; Liu, W.R.; Cai, H.H.; Lv, J.H.; Liu, J.D. Amorphous magnesium substituted mesoporous aluminophosphate: An acid-base sites synergistic catalysis for transesterification of diethyl carbonate and dimethyl carbonate in fixed-bed reactor. Microporous Mesoporous Mater. 2020, 292, 109757. [CrossRef]

37. Chada, R.R.; Ketike, T.; Boilla, A.R.; Gangadharam, S.D.; Kamaraju, S.R.R.; Burri, D.R. Preparation and characterization of lanthanum phosphate catalysts for O-methylation of phenol to anisole in gas phase. Mol. Catal. 2017, 438, 224-229. [CrossRef]

38. Nguyen, T.T.N.; Ruaux, V.; Massin, L.; Lorentz, C.; Afanasiev, P.; Maugé, F.; Bellière-Baca, V.; Rey, P.; Millet, J. Synthesis, characterization and study of lanthanum phosphates as light alcohols dehydration catalysts. Appl. Catal. B: Environ. 2014, 166, 432-444. [CrossRef] 